\title{
Traumatic evisceration after blunt trauma in a 20-month-old boy
}

\author{
Marta Diana Komarowska, M.D., Ewa Matuszczak, M.D., \\ Wojciech Debek, M.D., Adam Hermanowicz, M.D.
}

Department of Pediatric Surgery and Urology, Medical University of Bialystok, Children's Clinical Hospital, Bialystok-Poland

\begin{abstract}
Blunt traumatic evisceration is extremely rare. We describe the case of a 20-month-old boy with stomach and small and large intestine evisceration after blunt trauma. Immediate laparotomy and surgical repair were performed. There was no injury, other than a small hole in the mesentery. The bowels were drained into the abdominal cavity, and the skin was closed. The patient recovered well.
\end{abstract}

Keywords: Blunt trauma; emergent surgery; evisceration.

\section{INTRODUCTION}

There are only a few cases of traumatic abdominal evisceration in literature. A more common injury is traumatic abdominal wall hernia. This rare condition could be caused by penetration or blunt trauma. Most of the presented cases concern adult patients. In our report, we describe a case of traumatic abdominal wall disruption with stomach and bowel evisceration in a 20-month-old boy.

\section{CASE REPORT}

A 20-month-old boy was admitted to our Pediatric Emergency Department after he suffered a blunt abdominal wall injury. He was playing near the house when suddenly his older sister accidentally drove a car into him and pressed him into the concrete house wall. His parents immediately took him to their car and drove the child to the oncoming ambulance team. On examination at admission, he had signs of traumatic shock, but was conscious and scored 13 points on the Pediatric Glasgow Coma Scale. The vital signs were as follows: heart rate, 145 beats/min; blood pressure, 70/50 $\mathrm{mmHg}$; respiratory rate, 30 breaths $/ \mathrm{min}$; and temperature, $36.0^{\circ} \mathrm{C}$. The obvious injury was a protrusion of the greater part of the stomach and small and large bowels, with the omentum outside the abdominal wall, and some skin abrasions and bilateral contusions on the parietal region of the head and on both arms (Fig. Ia).

Abnormalities in laboratory tests included elevated aminotransferases (ALT $205 \mathrm{U} / \mathrm{l}$ and AST 35I U/I) and D-dimer $(7877 \mathrm{ng} / \mathrm{ml})$. Due to the mechanism of the trauma, after preliminary fluid resuscitation, computer tomography (CT) was performed (Fig. Ib). Besides evisceration, the CT scan demonstrated a first-grade left pulmonary contusion and small pneumothorax on the right side. The child was immediately taken to the operating theatre. We administered broad spectrum antibiotics (cefuroxime, metronidazole, and amikacin). Intraoperatively, we found an $8-\mathrm{cm}$ transverse wound in the umbilical region and some skin abrasion in the right lumbar and iliac regions. Exploration of the abdominal cavity and retroperitoneum was done through the full-thickness anterior abdominal wall rupture. To the right of the umbilicus, the anterior rectus fascia, rectus abdominal muscle, and peritoneum were damaged. We investigated and closed a $5-\mathrm{cm}$ defect in the mesentery. The stomach and the small and large intestines were not injured. We excluded other abdom-

Cite this article as: Komarowska MD, Matuszczak E, Debek W, Hermanowicz A. Traumatic evisceration after blunt trauma in a 20-month-old boy. Ulus Travma Acil Cerrahi Derg 2018;24:175-177

Address for correspondence: Adam Hermanowicz, M.D.

Waszyngtona 17 15-27 Bialystok, Poland

Tel: 6086I2288 E-mail: ahermanowicz@wp.pl

Ulus Travma Acil Cerrahi Derg 2018;24(2):175-177 DOI: 10.5505/tites.2017.37807 Submitted: 10.11.2017 Accepted: 01.12.2017 Online: I2.02.2018

Copyright 2018 Turkish Association of Trauma and Emergency Surgery 

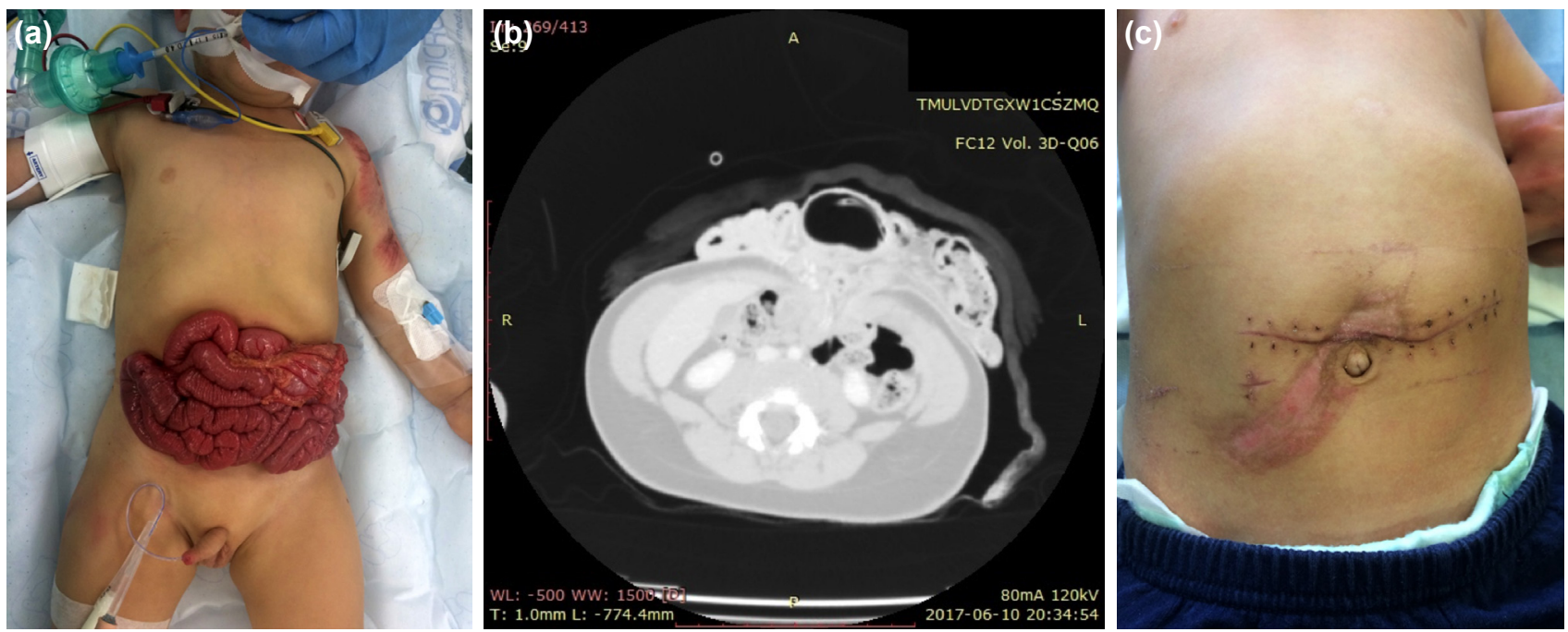

Figure 1. (a) Preoperative image showing small and large bowel evisceration. (b) Trauma scan shows evisceration of the stomach (with nasogastric tube inside) and small and large intestines. (c) Postoperative results. Two weeks after surgery.

inal damages. The eviscerated organs were cleaned with a warm saline solution and returned into the abdomen. The abdominal cavity was drained, and then the abdominal wall was reconstructed in whole layers. The postoperative period was complicated with diarrhea caused by Morganella morganii and was successfully treated using cefotaxime, a third-generation cephalosporin. The patient recovered well; he was discharged from the hospital 16 days after the accident and remains stable under ambulatory control (Fig. Ic).

\section{DISCUSSION}

The incidence of all abdominal wall injuries after blunt trauma is only $9 \% .^{\left[{ }^{[1]}\right.}$ Traumatic evisceration after blunt trauma is extremely rare. In most cases, it is associated with a penetrating injury. There are only a few reports in literature with this type of injury. To our knowledge, only two pediatric cases have been reported in literature. One case was of a 6-yearold boy with small bowel evisceration who felt onto bicycle handlebars. ${ }^{[2]}$ The other was a 7-year-old girl after a motor vehicle accident and with small and large intestine evisceration. ${ }^{[3]}$ In both cases, a laparotomy and primary closing were performed. The postoperative period was uneventful.

Table I. Abdominal wall injury grading scale ${ }^{[1]}$

\begin{tabular}{ll}
\hline Grade & Description \\
\hline I & Subcutaneous tissue contusion \\
II & Abdominal wall muscle hematoma \\
III & Singular abdominal wall muscle disruption \\
IV & Complete abdominal wall muscle disruption \\
V & Complete abdominal wall muscle disruption with \\
& herniation of the abdominal contents \\
VI & Complete abdominal wall disruption with evisceration \\
\hline
\end{tabular}

Based on the CT scan findings, complete abdominal wall disruption with evisceration was extreme (grade $\mathrm{VI}$ on the abdominal wall injury grading scale) (Table I). ${ }^{[4]}$ The causes of injury differ and could be due to high or low energy mechanisms (accidents, falls, handlebar injury). Evisceration is obvious and can occur in natural orifices (anus, ${ }^{[5]}$ vagina, diaphragm) or in anatomically weak places (lateral rectus, lower abdomen, because of the absence of a posterior rectus sheath in this area, and inguinal canal). ${ }^{[6]}$ Every time a patient is hemodynamically stable, other injuries must be excluded, and a trauma CT should be performed, ${ }^{[6]}$ because the frequency of the associated intra-abdominal damage could be $30 \%{ }^{[7]}$ Obviously, the procedure of choice is prompt laparotomy and surgical repair. ${ }^{[4]}$ The best option is primary wall closure, but when there is a giant abdominal wall defect, we can temporarily cover the defect with absorbable or non-absorbable mesh, any other surgical material (even urine bags and intravenous fluid bags were described), or a vacuum pack dressing. ${ }^{[8]}$ We should remember that a fascia closure with tension could lead to necrosis of the fascia or life-threatening abdominal compartment syndrome. Other early complications include wound infection and enteric fistula formation. ${ }^{[9]}$ All patients should stay under long-term follow-up care to observe the functional and cosmetic outcomes.

\section{Conclusion}

Traumatic abdominal evisceration after blunt injury is extremely rare. If the patient is clinically stable, associated injuries should be excluded before an operation using CT. Exploratory laparotomy is mandatory, and if possible, primary abdominal wall closure should be performed. Isolated evisceration is potentially life-threating, but has a very good prognosis, if adequate treatment is immediately provided.

Conflict of interest: None declared. 


\section{REFERENCES}

1. Dennis RW, Marshall A, Deshmukh H, Bender JS, Kulvatunyou N, Lees JS, et al. Abdominal wall injuries occurring after blunt trauma: incidence and grading system. Am J Surg 2009;197:413-7. [CrossRef]

2. Nguyen MH, Watson A, Wong E. A 6-year-old boy presenting with traumatic evisceration following a bicycle handle bar injury: a case report. Cases J 2009;2:6315. [CrossRef]

3. van $A s A B$, Rode $H$. Evisceration through multiple abdominal wall defects following blunt abdominal injury. Pediatr Emerg Care 2003;19:353-4.

4. McDaniel E, Stawicki SP, Bahner DP. Blunt traumatic abdominal wall disruption with evisceration. Int J Crit Illn Inj Sci 2011;1:164-6. [CrossRef]

5. Gelas T, Combet S, Perinel J, Javouhey E, Mure PY. Transrectal small bowel evisceration after abdominal crush injury. J Pediatr Surg 2012;47:e53-6. [CrossRef]

6. Choi HJ, Park KJ, Lee HY, Kim KH, Kim SH, Kim MC, et al. Traumatic abdominal wall hernia (TAWH): a case study highlighting surgical management. Yonsei Med J 2007;48:549-53. [CrossRef]

7. Ganchi PA, Orgill DP. Autopenetrating hernia: a novel form of traumatic abdominal wall hernia-case report and review of the literature. J Trauma 1996;41:1064-6. [CrossRef]

8. Jernigan TW, Fabian TC, Croce MA, Moore N, Pritchard FE, Minard $\mathrm{G}$, et al. Staged management of giant abdominal wall defects: acute and long-term results. Ann Surg 2003;238:349-55. [CrossRef]

9. Bansal S, Jain S, Meena LN. Staged management of giant traumatic abdominal wall defect: A rare case report. Burns Trauma 2013;1:144-7.

\section{OLGU SUNUMU - ÖZET}

\section{Yirmi aylık erkek çocukta künt travmadan sonra travmatik eviserasyon}

\section{Dr. Marta Diana Komarowska, Dr. Ewa Matuszczak, Dr. Wojciech Debek, Dr. Adam Hermanowicz}

Bialystok Tıp Fakültesi, Çocuk Klinikleri Hastanesi, Çocuk Cerrahisi ve Üroloji Bölümü, Bialystok, Polonya

Künt travmaya bağlı eviserasyon son derece nadirdir. Yirmi aylık erkek çocukta künt travma sonrası mide, ince ve kalın bağırsakta eviserasyonu tanımladık. Acil laparotomi ve cerrahi onarım yapılmıştı. Mezenterde küçük bir delikten başka bir yaralanma yoktu. Bağırsaklar karın boşluğuna drene edildi ve cilt kapatıldı. Hasta iyileşti.

Anahtar sözcükler: Acil cerrahi; eviserasyon; künt travma.

Ulus Travma Acil Cerrahi Derg 2018;24(2): I75-177 doi: 10.5505/tjtes.2017.37807 